\title{
PEMILIHAN PAKET WISATA MENGGUNAKAN METODE ANALYTICAL HIERARCHY PROCESS (AHP)
}

\author{
Mulya Ade Irma Suryani 1), Zainal Arifin ${ }^{2)}$, Heliza Rahmania Hatta ${ }^{3)}$ \\ ${ }^{1,2,3)}$ Program Studi Ilmu Komputer,Fakultas Ilmu Komputer dan Teknologi Informasi Universitas Mulawarman \\ Alamat Jl. Panajam Kampus Gunung Kelua Universitas Mulawarman Samarinda \\ E-Mail : mulyaade010@gmail.com ${ }^{1)}$; zainal_arifin@fkti.unmul.ac.id ${ }^{2)}$; heliza_rahmania@yahoo.com ${ }^{3)}$;
}

\begin{abstract}
ABSTRAK
Pengambilan keputusan sebelum melakukan perjalanan wisata merupakan hal yang penting.Masalah biasanya terjadi dalam pengambilan keputusan tidak cukupnya informasi, banyak informasi yang tidak akurat, dan banyak lagi. Hal ini juga terjadi dalam pengambilan keputusan untuk memilih paket liburan. Penelitian ini difokuskan pada penerapan Metode Analytical Hierarchy Process (AHP) pada Sistem Pendukung Keputusan (SPK) Pemilihan Paket Wisata. Dalam hal ini penulis mengambil tiga kriteria sebagai atribut untuk proses pengolahan data yakni Biaya (Ketersediaan dana oleh user), Lama Perjalanan (Estimasi waktu yang diinginkan user) dan Fasilitas Hotel yang disediakan. Penelitian ini menghasilkan sebuah aplikasi web yang memberikan informasi rekomendasi pada user atau pengguna dalam hal ini merupakan calon wisatawan. Rekomendasi yang diberikan sistem didasarkan pada masukan yang diberikan user kemudian diproses dengan metode Analytical Hierarchy Process (AHP) sehingga menghasilkan rekomendasi daftar paket wisata.
\end{abstract}

Kata Kunci : Sistem Pendukung Keputusan, Perjalanan, AHP.

\section{PENDAHULUAN}

Perkembangan teknologi informasi yang semakin hari semakin meningkat. Membuat dampak yang cukup besar dalam seluruh aspek kehidupan dan membawa manusia ke dalam era globalisasi, dimana pada era ini manusia memerlukan informasi yang terbaru (up to date) dengan cepat, praktis, efisien. Internet adalah salah satu teknologi yang sangat pesat perkembangannya dan sudah merupakan simbol dari cara berkomunikasi secara bebas, tanpa dibatasi uang, jarak dan waktu. Informasi yang disajikan pun tidak terbatas pada teks dan gambar saja. Melainkan juga suara dan animasi gambar yang membuatnya menjadi interaktif. Dengan ditunjang oleh berbagai kelebihan yang dimiliki oleh internet, diantaranya biaya koneksi yang relatif terjangkau dan ketersediaan informasi yang tidak terbatas, internet kini menjadi alternatif utama untuk memenuhi segala kebutuhan terutama kebutuhan akan informasi.

Dalam sektor bisnis khususnya pariwisata, peranan internet sangatlah dibutuhkan.selain sebagai sarana promosi dan informasi tempat wisata, juga bisa dimanfaatkan juga oleh agen perjalanan untuk memperkenalkan layanan dan alternatif paket wisata yang ditawarkan. Dengan adanya banyak pilihan paket wisata ditawarkan agen perjalanan ini, maka para calon wisatawan akan dihadapkan dengan kesulitan dalam melakukan pilihan terlebih lagi menyesuaikan pilihan faktor kriteria yang berpengaruh terhadap pilihan. Proses pemesanan juga biasanya masih dilakukan secara manual, sehingga calon wisatawan tidak dapat melakukan pemilihan dan pemesanan dengan leluasa. Pada penelitian sebelumnya yang berjudul "Proses
Pemilihan Vendor Di PT FBMI Dengan Metode Analytical Hierarchy Process (AHP)" oleh Yulia Ayu Asyari (2015) menjelaskan tentang pengambilan keputusan ialah proses memilih suatu alternatif cara bertindak dengan metode yang efisien sesuai situasi. Proses ini digunakan untuk menemukan dan menyelesaikan masalah yang ada. Tidak hanya dalam masalah-masalah individu, pemilihan juga sering dihadapi oleh organisasi. Beragamnya kriteria yang harus dipertimbangkan dan banyaknya alternatif yang dapat dipilih, menyebabkan seorang pengambil keputusan harus dapat menentukan prioritas untuk masing-masing alternatif yang ada.

Berdasarkan permasalahan tersebut penulis berkeinginan untuk merancang suatu sistem pendukung keputusan pemilihan paket wisata berbasis web selain dapat untuk membantu dalam hal mempromosikan agen perjalanan ini, juga dapat mempermudah wisatawan untuk melakukan proses pemilihan paket wisata dan pemesanan paket wisata.

\section{TINJAUAN PUSAKA}

\section{A. Sistem Pendukung Keputusan}

Sistem Pendukung Keputusan adalah suatu pendekatan (atau metodologi) untuk mendukung pengambilan keputusan yang fleksibel, interaktif dan dapat diadaptasi yang dikembangkan untuk mendukung solusi untuk masalah manajemen spesifik yang tidak terstruktur, menggunakan data, memberikan antarmuka pengguna yang mudah dan dapat menggabungkan pemikiran pengambil keputusan. Konsep Sistem Pendukung Keputusan (SPK) (Decision Support System (DSS)) pertama kali diungkapkan pada awal tahun 1970-an oleh Michael 


\section{S. Scott Morton dengan istilah Management Decision} System.

\section{B. Analytical Hierarchy Process (AHP)}

Analytical Hierarchy Process (AHP) adalah suatu metode analisis dan sintesis yang dapat membantu proses Pengambilan Keputusan. AHP merupakan alat pengambil keputusan yang powerful dan fleksibel yang dapat membantu dalam menetapkan prioritasprioritas dan membuat keputusan dimana aspek aspek kualitatif dan kuantitatif terlibat dan keduanya harus dipertimbangkan. Dengan mereduksi faktorfaktor yang kompleks menjadi rangkaian "one on one comparisons" dan kemudian mensintesa hasil hasilnya, maka AHP tidak hanya membantu orang dalam memilih keputusan yang tepat tetapi juga dapat memberikan pemikiran/alasan yang jelas dan tepat. (Turban, 2005) Proses pengambilan keputusan pada dasarnya adalah memilih suatu alternatif. Peralatan utama AHP adalah sebuah hierarki fungsional dengan input utamanya persepsi manusia. Keberadaan hierarki memungkinkan dipecahnya masalah kompleks atau tidak terstruktur dalam subsub masalah lalu menyusunnya menjadi suatu bentuk hierarki. (Kusrini, 2007) .Permasalahan yang diselesaikan dengan AHP memiliki beberapa prinsip, diantaranya adalah (Kusrini, 2007) :

1. Membuat hierarki yakni memahami sebuah sistem yang kompleks, dapat dilakukan dengan memecah sistem tersebut menjadi elemenelemen pendukung, menyusun elemen secara hierarki dan menggabungkannya atau mensintesiskan sistem tersebut.

2. Penilaian kriteria dan alternatif yakni kriteria dan alternatif dapat ditentukan dengan perbandingan berpasangan.

\section{Paket Wisata}

Paket wisata (package tour) adalah produk perjalanan yang dijual oleh suatu perusahaan biro perjalanan atau perusahaan transport yang bekerja sama dengannya dimana harga paket wisata tersebut telah mencakup biaya perjalanan, hotel ataupun fasilitas lainnya (Suwantoro: 1997). Sedangkan menurut Yoeti (1997), paket wisata merupakan suatu perjalanan wisata yang direncanakan dan diselenggarakan oleh suatu travel agent atau biro perjalanan atas resiko dan tanggung jawab sendiri baik acara, lama waktu wisata dan tempat yang akan dikunjungi, akomodasi, transportasi, serta makanan dan minuman telah ditentukan oleh biro perjalanan dalam suatu harga yang telah ditentukan jumlahnya.

\section{HASIL DAN PEMBAHASAN}

\section{A. Analisis Sistem}

Website pemilihan paket wisata ini dapat melakukan penentuan paket wisata yang akan dipilih berdasarkan kriteria yang sudah ditentukan dengan menerapkan metode Analytical Hierarchy Process (AHP). Dalam metode ini admin akan memberikan data paket wisata yang sesuai. Sistem akan melakukan perhitungan dengan metode Analytical Hierarchy Process (AHP) untuk mendapatkan paket wisata yang sesuai dengan keinginan user dengan berdasarkan kriteria - kriteria yang sudah ditetapkan. Untuk mendukung pembuatan website ini, data paket wisata didapatkan dari StarWisata Tour and Travel. Sehingga sistem ini dapat bekerja layaknya sebuah sistem yang telah di - implementasikan secara nyata.

\section{B. Perancangan Sistem}

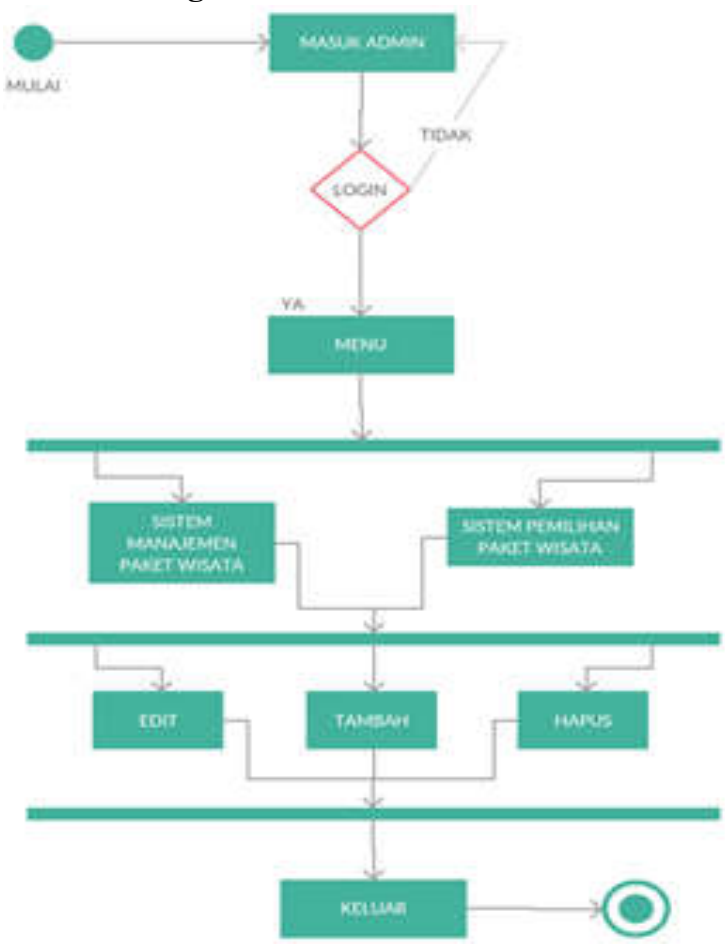

Gambar 1. Activity Diagram Pemilihan Paket Wisata

Pada Gambar. 1 ditunjukan bahwa admin dapat login dan masuk kedalam menu sistem memiliki akses penuh terhadap sistem manajemen paket wisata dan sistem pemilihan paket wisata.Admin dapat mengubah, menambah maupun manghapus data yang terdapat dalam sistem Pemilihan Paket Wisata.

\section{Perancangan Database}

Struktur tabel yang digunakan dalam pembuatan website ini dapat dilihat pada tabel - tabel

\section{Tabel Paket Wisata}

Digunakan untuk menyimpan data - data mengenai paket wisata.

Tabel 1. Struktur Tabel Data Paket Wisata

\begin{tabular}{|l|c|c|c|}
\hline \multicolumn{1}{|c|}{ Field Name } & Data Type & $\begin{array}{c}\text { Field } \\
\text { Size }\end{array}$ & Description \\
\hline Id_paket & int & 5 & - \\
\hline Musim_paket & int & 1 & - \\
\hline Negara_paket & int & 1 & - \\
\hline Harga_paket & varchar & 20 & - \\
\hline Hari_paket & int & 2 & - \\
\hline Malam_paket & int & 2 & - \\
\hline Tiket_paket & int & 2 & - \\
\hline Hotel_paket & int & 2 & - \\
\hline Pemandu_paket & int & 2 & - \\
\hline Makan_paket & int & 2 & - \\
\hline Wisata paket & text & - & - \\
\hline Min_paket & int & 2 & - \\
\hline Nama_paket & varchar & 50 & - \\
\hline \multicolumn{4}{|l}{}
\end{tabular}




\section{Pengujian Sistem}

Pengujian ini dilakukan untuk mengetahui kesamaan hasil akhir atau output yang berupa paket wisata yang sesuai yang dihasilkan sistem, dengan yang dihasilkan perhitungan secara manual. Untuk mengetahui hasil output dari sistem , operator harus memberikan data - data paket wisata yang diperlukan berupa ; nama paket wisata, harga, lama perjalanan, dan akomodasi paket yang disediakan. Kemudian, akan muncul pada halaman hasil setelah tombol proses ditekan.

1. Menyusun Hierarki Permasalahan

Untuk menentukan pilihan pada paket wisata yang sesuai memerlukan startegi serta kriteria yang sesuai sehingga dihasilkan suatu keputusan yang tepat. Dimana harga, lama perjalanan dan hotel yang disediakan paket mempengaruhi hasil keputusan.

a. Harga ,Kriteria ini berpengaruh dengan kebutuhan akan paket wisata yang diinginkan oleh konsumen.

b. Lama perjalanan, Kriteria ini berpengaruh dengan seberapa lama waktu perjalanan yang diinginkan konsumen dengan menyesuaikan kebutuhan konsumen.

c. Hotel, Kriteria ini berpengaruh kepada tingkat kenyaman yang diinginkan oleh konsumen pada saat menginap di hotel selama perjalanan wisata.

2. Penilaian Kriteria dan Alternative

Untuk nilai diagonal matriks perbandingan suatu elemen dengan elemen itu sendiri diisi dengan bilangan 1. Matriks perbandingan persamaan dapat dilihat pada Tabel 2. Kriteria dan alternative dinilai melalui matriks perbandingan berpasangan (pairwise comparison matrix) yang dilakukan berdasarkan manajemen dari pengambilan keputusan dengan menilai tingkat kepentingan suatu elemen dengan elemen lainnya dengan skala 1 sampai 9 berdasarkan skala perbandingan pada Tabel 3 .

Tabel 2. Matriks Perbandingan Persamaan

\begin{tabular}{|l|c|c|c|}
\hline Kriteria & Harga & Hotel & $\begin{array}{l}\text { Lama } \\
\text { Perjalanan }\end{array}$ \\
\hline Harga & 1 & 3 & 4 \\
\hline Hotel & 0,33 & 1 & 2 \\
\hline Lama Perjalanan & 0,25 & 0,50 & 1 \\
\hline$\sum$ & 1,58 & 4,50 & 7 \\
\hline
\end{tabular}

3. Setelah matriks perbandingan berpasangan (pairwise comparison matrix) terebentuk. selanjutnya pertimbangan - pertimbangan terhadap perbandingan berpasangan disitensis dengan melakukan suatu pembobotan yang akan menghasilkan suatu prioritas setiap elemen kriteria.Nilai - nilai perbandingan relati dari seluruh aternatif kriteria dapat disesuaikan dengan judgement yang telah ditentukan untuk menghasilkan bobot dan prioritas. Hasil pembobotan prioritas elemen dapat dilihat pada Tabel 4

Tabel 3. Tabel Skala Fundamental

\begin{tabular}{|c|l|l|}
\hline $\begin{array}{c}\text { Tingkat } \\
\text { Kepentin } \\
\text { gan }\end{array}$ & \multicolumn{1}{|c|}{ Definisi } & \multicolumn{1}{c|}{ Keterangan } \\
\hline 1 & $\begin{array}{l}\text { Equal } \\
\text { importance } \\
\text { (sama penting) }\end{array}$ & $\begin{array}{l}\text { Kedua elemen sama } \\
\text { pentingnya/memiliki } \\
\text { pengaruh yang sama }\end{array}$ \\
\hline 3 & $\begin{array}{l}\text { Weak importance of } \\
\text { one over } \text { (sedikit } \\
\text { lebih penting) }\end{array}$ & $\begin{array}{l}\text { Elemen yang satu sedikit } \\
\text { lebih penting daripada } \\
\text { elemen yang lainnya }\end{array}$ \\
\hline 5 & $\begin{array}{l}\text { Essential } \text { or strong } \\
\text { importance (lebih } \\
\text { penting) }\end{array}$ & $\begin{array}{l}\text { Elemen yang satu lebih } \\
\text { penting daripada yang } \\
\text { lainnya. }\end{array}$ \\
\hline 7 & $\begin{array}{l}\text { Demonstrate } \\
\text { dimportance } \\
\text { (sangat } \\
\text { penting) }\end{array}$ & $\begin{array}{l}\text { Satu elemen } \\
\text { jelas lebih mutlak } \\
\text { penting daripada elemen } \\
\text { lainnya }\end{array}$ \\
\hline 9 & $\begin{array}{l}\text { Extreme Importance } \\
\text { (mutlak lebih } \\
\text { penting) }\end{array}$ & $\begin{array}{l}\text { Satu elemen mutlak } \\
\text { penting daripada elemen } \\
\text { lainnya }\end{array}$ \\
\hline $2,4,6,8$ & $\begin{array}{l}\text { Intermediate values } \\
\text { between the two } \\
\text { adjacent judgements }\end{array}$ & $\begin{array}{l}\text { Nilai diantara dua nilai } \\
\text { Pertimbanganpertimbang } \\
\text { an yang berdekatan }\end{array}$ \\
\hline Resiprok & $\begin{array}{l}\text { Kebalikan } \\
\text { al }\end{array}$ & $\begin{array}{l}\text { Jika elemen I mendapat } \\
\text { satu angka dibandingkan } \\
\text { dengan elemen j, maka j } \\
\text { memiliki nilai } \\
\text { kebalikannya } \\
\text { dibandingkan dengan i }\end{array}$ \\
\hline
\end{tabular}

Tabel 4. Matriks Bobot Prioritas Kriteria

\begin{tabular}{|c|c|c|c|c|c|}
\hline Kriteria & Harga & Hotel & $\begin{array}{c}\text { Lama } \\
\text { Perjalanan }\end{array}$ & $\sum$ & $\begin{array}{c}\text { Bobot } \\
\text { Prioritas }\end{array}$ \\
\hline Harga & 0,63 & 0,67 & 0,57 & 1,87 & 0,62 \\
\hline Hotel & 0,21 & 0,22 & 0,29 & 0,72 & 0,24 \\
\hline $\begin{array}{c}\text { Lama } \\
\text { Perjalanan }\end{array}$ & 0,16 & 0,11 & 0,14 & 0,41 & 0,14 \\
\hline$\sum$ & 1,00 & 1,00 & 1,00 & 3,00 & 1,00 \\
\hline
\end{tabular}

Nilai pada sel baru diperoleh melalui perhitungan nilai sel pada matriks perbandingan berpasangan. Sedangkan untuk nilai bobot prioritas diperoleh melalui nilai pada jumlah dibagi dengan jumlah elemen kriteria.

4. Pengukuran konsistensi

Untuk mengetahui konsistensi matriks perbandingan maka dibuat matriks dengan mengalikan nilai bobot prioritas tiap elemen pada matrik perbandingan berpasangan (bobot prioritas elemen pertama dikali dengan setiap nilai pada kolom pertama dari matriks perbandingan berpasangan) selanjutnya hasil penjumlahan baris tersebut dibagi dengan nilai bobot prioritas tiap elemen sehingga dihasilkan nilai bobot . Hasil dari matriks konsistensi kriteria dapat dilihat pada Tabel 5.

Tabel 5. Matriks Konsistensi Kriteria

\begin{tabular}{|l|l|l|l|}
\hline Kriteria & Harga & Hotel & Lama Perjalanan \\
\hline Harga & 0,62 & 0,15 & 0,03 \\
\hline Hotel & 1,87 & 0,24 & 0,07 \\
\hline Lama Perjalanan & 2,49 & 0,14 & 0,14 \\
\hline$\sum$ & 1,89 & 0,72 & 0,41 \\
\hline Bobot Prioritas & 3,034 & 3,014 & 3,007 \\
\hline
\end{tabular}


AHP mengukur konsistensi menyeluruh dari berbagai pertimbangan melalui Consistency Ratio (CR). Jika nilai Consistency Ratio (CR) kurang dari atau sama dengan 0,1 ( $\mathrm{CR} \leq 0,1$ ) maka Consistency Ratio (CR) dapat dinyatakan benar atau konsiten dan dapat diterima atau dapat dilanjutkan tetapi jika nilai Consistency Ratio (CR) lebih dari 0,1 (CR $\geq 0,1)$ maka dikatakan pengukuran tidak konsisten sehingga perlu dilakukan ulang perbandingan berpasangannya. Untuk memperoleh nilai Consistency Ratio (CR) maka digunakan rumus :

$\mathrm{CR}=\left(\left(\lambda \_(\text {maks })-\mathrm{n}\right) / \mathrm{n}\right) / 0,58$

Dimana :

$\lambda \_(\text {maks ): jumlah nilai bobot atau jumlah kriteria. }$

n : jumlah kriteria.

5. Penentuan prioritas

Untuk setiap kriteria dan alternative, perlu dilakukan perbandingan berpasangan. Nilai nilai perbandingan relative kemudian diolah dengan melakukan suatu pembobotan dan jumlah untuk menentukan prioritas atau peringkat alternative dari seluruh alternatif. Matrik perbandingan untuk alternative dibuat berdasarkan masing - masing kriteria. Langkah membuat matriks perbandingan dan menentukan bobot prioritas untuk alternative sama halnya dengan membuat matriks perbandingan serta menentukan bobot prioritas kriteria. Matriks perbandingan alternatif dan matriks bobot prioritas harga Tabel 6.

Tabel 6. Matriks Perbandingan Pemilihan Paket Wisata Berdasarkan Harga

\begin{tabular}{|l|l|l|l|l|l|}
\hline Harga & AL 1 & AL 2 & AL 3 & AL 4 & AL 5 \\
\hline AL 1 & 1,00 & 3,00 & 2,00 & 5,00 & 5,00 \\
\hline AL 2 & 0,33 & 1,00 & 3,00 & 5,00 & 5,00 \\
\hline AL 3 & 0,50 & 0,33 & 1,00 & 2,00 & 2,00 \\
\hline AL 4 & 0,20 & 0,20 & 0,50 & 1,00 & 2,00 \\
\hline AL 5 & 0,20 & 0,20 & 0,50 & 0,50 & 1,00 \\
\hline
\end{tabular}

Tabel 7. Matriks Bobot Prioritas Pemilihan Paket Wisata Berdasarkan Harga

\begin{tabular}{|c|c|c|c|c|c|}
\hline Harga & AL 1 & AL 2 & AL 3 & AL 4 & AL 5 \\
\hline AL 1 & 0,81 & 0,27 & 0,41 & 0,16 & 0,16 \\
\hline AL 2 & 1,73 & 0,58 & 0,19 & 0,12 & 0,12 \\
\hline AL 3 & 0,40 & 0,60 & 0,20 & 0,10 & 0,10 \\
\hline AL 4 & 0,59 & 0,59 & 0,24 & 0,12 & 0,06 \\
\hline AL 5 & 0,50 & 0,50 & 0,20 & 0,20 & 0,10 \\
\hline$\sum$ & 4,03 & 2,54 & 1,23 & 0,70 & 0,54 \\
\hline $\begin{array}{c}\text { Bobot } \\
\text { Prioritas }\end{array}$ & 0,45 & 0,28 & 0,14 & 0,08 & 0,06 \\
\hline
\end{tabular}

Tabel 8. Matriks Perbandingan Pemilihan Paket Wisata Berdasarkan Hotel

\begin{tabular}{|l|l|l|l|l|l|}
\hline Hotel & AL 1 & AL 2 & AL 3 & AL 4 & AL 5 \\
\hline AL 1 & 1,00 & 3,00 & 5,00 & 5,00 & 3,00 \\
\hline AL 2 & 0,33 & 1,00 & 3,00 & 2,00 & 2,00 \\
\hline AL 3 & 0,20 & 0,33 & 1,00 & 2,00 & 2,00 \\
\hline AL 4 & 0,20 & 0,25 & 0,50 & 1,00 & 2,00 \\
\hline AL 5 & 0,33 & 0,33 & 0,50 & 0,50 & 1,00 \\
\hline
\end{tabular}

Tabel 9. Matriks Bobot Prioritas Pemilihan Paket Wisata Berdasarkan Hotel

\begin{tabular}{|l|l|l|l|l|l|}
\hline Hotel & AL 1 & AL 2 & AL 3 & AL 4 & AL 5 \\
\hline AL 1 & 0,48 & 0,16 & 0,10 & 0,10 & 0,16 \\
\hline AL 2 & 0,61 & 0,20 & 0,07 & 0,05 & 0,07 \\
\hline AL 3 & 0,50 & 0,30 & 0,10 & 0,05 & 0,05 \\
\hline AL 4 & 0,48 & 0,19 & 0,19 & 0,10 & 0,05 \\
\hline AL 5 & 0,30 & 0,20 & 0,20 & 0,20 & 0,10 \\
\hline$\sum$ & 2,37 & 1,06 & 0,66 & 0,49 & 0,43 \\
\hline $\begin{array}{l}\text { Bobot } \\
\text { Prioritas }\end{array}$ & 0,47 & 0,21 & 0,13 & 0,10 & 0,09 \\
\hline
\end{tabular}

Tabel 10. Matriks Perbandingan Pemilihan Paket Wisata Berdasarkan Lama Perjalanan

\begin{tabular}{|l|c|c|c|c|c|}
\hline $\begin{array}{l}\text { Lama } \\
\text { Perjalanan }\end{array}$ & AL 1 & AL 2 & AL 3 & AL 4 & AL 5 \\
\hline AL 1 & 1,00 & 5,00 & 5,00 & 5,00 & 5,00 \\
\hline AL 2 & 0,20 & 1,00 & 3,00 & 2,00 & 2,00 \\
\hline AL 3 & 0,20 & 0,33 & 1,00 & 2,00 & 2,00 \\
\hline AL 4 & 0,20 & 0,50 & 0,50 & 1,00 & 2,00 \\
\hline AL 5 & 0,20 & 0,50 & 0,50 & 0,50 & 1,00 \\
\hline
\end{tabular}

Tabel 11. Matriks Bobot Prioritas Pemilihan Paket Wisata Berdasarkan Lama Perjalanan

\begin{tabular}{|l|l|l|l|l|l|}
\hline $\begin{array}{l}\text { Lama } \\
\text { Perjalanan }\end{array}$ & AL 1 & AL 2 & AL 3 & AL 4 & AL 5 \\
\hline AL 1 & 0,56 & 0,11 & 0,11 & 0,11 & 0,11 \\
\hline AL 2 & 0,68 & 0,14 & 0,05 & 0,07 & 0,07 \\
\hline AL 3 & 0,50 & 0,30 & 0,10 & 0,05 & 0,05 \\
\hline AL 4 & 0,48 & 0,19 & 0,19 & 0,10 & 0,05 \\
\hline AL 5 & 0,42 & 0,17 & 0,17 & 0,17 & 0,08 \\
\hline$\sum$ & 2,63 & 0,90 & 0,61 & 0,49 & 0,36 \\
\hline $\begin{array}{l}\text { Bobot } \\
\text { prioritas }\end{array}$ & 0,53 & 0,18 & 0,12 & 0,10 & 0,07 \\
\hline
\end{tabular}

Dari masing - masing bobot prioritas kriteria terhadap alternative pemilihan paket wisata maka selanjutnya dilakukan perkalian dari masing masing bobot kriteria dengan bobot dari masing masing alternative paket wisata sehingga didapatkan total dari bobot prioritas. Matriks total bobot prioritas dapat dilihat pada Tabel 12 . 
Tabel 12 Matriks Total Bobot Prioritas

\begin{tabular}{|l|l|l|l|l|}
\hline \multicolumn{1}{|r|}{ Kriteria } & Harga & Hotel & $\begin{array}{l}\text { Lama } \\
\text { Perjal } \\
\text { anan } \\
\text { natif } \\
\begin{array}{l}\text { Paket } \\
\text { Wisata }\end{array}\end{array}$ & $\begin{array}{l}\text { Total } \\
\text { Bobot } \\
\text { Prioritas }\end{array}$ \\
\hline AL 1 & 0,28 & 0,11 & 0,07 & 0,47 \\
\hline AL 2 & 0,17 & 0,05 & 0,03 & 0,25 \\
\hline AL 3 & 0,09 & 0,03 & 0,02 & 0,13 \\
\hline AL 4 & 0,05 & 0,02 & 0,01 & 0,09 \\
\hline AL 5 & 0,04 & 0,02 & 0,01 & 0,07 \\
\hline
\end{tabular}

Dari jumlah total bobot prioritas pada Tabel 4.12 dihasilkan keputusan bahwa priritas pemilihan paket wisata ada pada AL1( Alternatif 1) karena memiliki total bobot prioritas yang paling tinggi yaitu 0.47 dibanding 4 alternatif lainnya.

\section{KESIMPULAN}

Berdasarkan hasil penelitian mengenai penerapan metode Analytical Hierarchy Process (AHP) pemilihan paket wisata, dapat diambil kesimpulan telah dibangun aplikasi pemilihan paket wisata dengan menerapkan metode Analytical Hierarchy Process (AHP). Pengguna (User) dari aplikasi ini dapat melakukan pemilihan paket wisata yang sesuai dengan kriteria yang ditentukan. Sistem Penunjang keputusan ini bekerja berdasarkan bobot kriteria yang ditentukan dari hasil kuesioner yang akan dilakukan untuk perhitungan menggunakan metode Analytical Hierarchy Process (AHP), dengan input bobot oleh pengguna. Dalam proses pemilihan paket wisata dengan melakukan perhitungan nilai bobot antar kriteria dan alternative-alternative yang ada pada Tabel 4. Dalam proses penentuan bobot terdapat 3 kriteria ( Harga, Lama Perjalanan, dan Hotel ) dan 5 alternativ paket wisata yang sudah dipilih.

\section{DAFTAR PUSTAKA}

[1]. Yoeti, Oka. 1997. Perencanaan dan Pengembangan Pariwisata. PT Pradnya Paramita. Jakarta

[2]. Khairina, Dyna Marisa.2012. Analytical Hierarchy Process Sebagai Pendukung Keputusan (Decision Support) Pemilihan Lokasi Pembangunan Rumah Kos Untuk Karyawan. Jurnal Informatika. Vol 7. No 3. Edisi September 2012. Hal. 75 - 81.

[3]. Kosasi, S. 2002. Sistem Penunjang Keputusan (Decision Support System).

[4]. Kusrini. 2007. Konsep Dan Aplikasi Sistem Penunjang Keputusan. Andi. Yogyakarta

[5]. Turban, E., Aronson, J., dan Liang, P. T. 2005. Decision Support Systems and Intelligent Systems (Sistem Pendukung Keputusan dan Sistem Cerdas) Jilid I. Edisi Bahasa Indonesia. Yogyakarta : Andi Offset. 